\title{
Urbanization in developing economies: the assessment
}

\author{
Paul Collier* and Anthony J. Venables**
}

\begin{abstract}
Urbanization is an inherent part of economic development, yet its success in delivering jobs, productivity, and liveability varies widely. This issue of the Oxford Review of Economic Policy compares the experience of different countries and analyses the causes of their different performance. Cities are policy intensive, requiring public provision of infrastructure, regulation, and coordination. This in turn requires authorizing environments with a sufficiently broad span of control, and correspondingly powerful checks and balances to prevent abuse.
\end{abstract}

Keywords: urban, city, economic development, agglomeration, governance, Africa, China JEL classification: $01,018, \mathrm{R} 1$

* University of Oxford and International Growth Centre, e-mail: paul.collier@ bsg.ox.ac.uk ** University of Oxford and International Growth Centre, e-mail:

tony.venables@economics.ox.ac.uk

Thanks to the editors for helpful comments. We gratefully acknowledge the support of an Africa Research Programme on Spatial Development of Cities at LSE and Oxford funded by the Multi Donor Trust Fund on Sustainable Urbanization of the World Bank and supported by the UK Department for International Development.

\section{Introduction}

Urbanization happens everywhere: it is unstoppable, regardless of what government does. There is a near universal relationship between development and urbanization, with the rate at which urbanization occurs peaking at per capita income levels of around $\$ 3,000-5,000$. These levels were reached in most of Europe, North America, and Japan more than a century ago, in Latin America in the 1960s, have now been passed by East Asia, and are being approached by South Asia and Africa. The historical record and projections for future urban populations are given in Figure 1. Asian cities will add more than 1 billion people to their populations by 2050, and Africa will add around $800 \mathrm{~m}$. For sub-Saharan Africa, urbanizing at lower per capita income levels than has been historical experience elsewhere, urban population will more than treble, from 350m in 2014 to 1.1 billion in 2050 (UN, 2014, Annex Table 1). 
Figure 1: Urban population

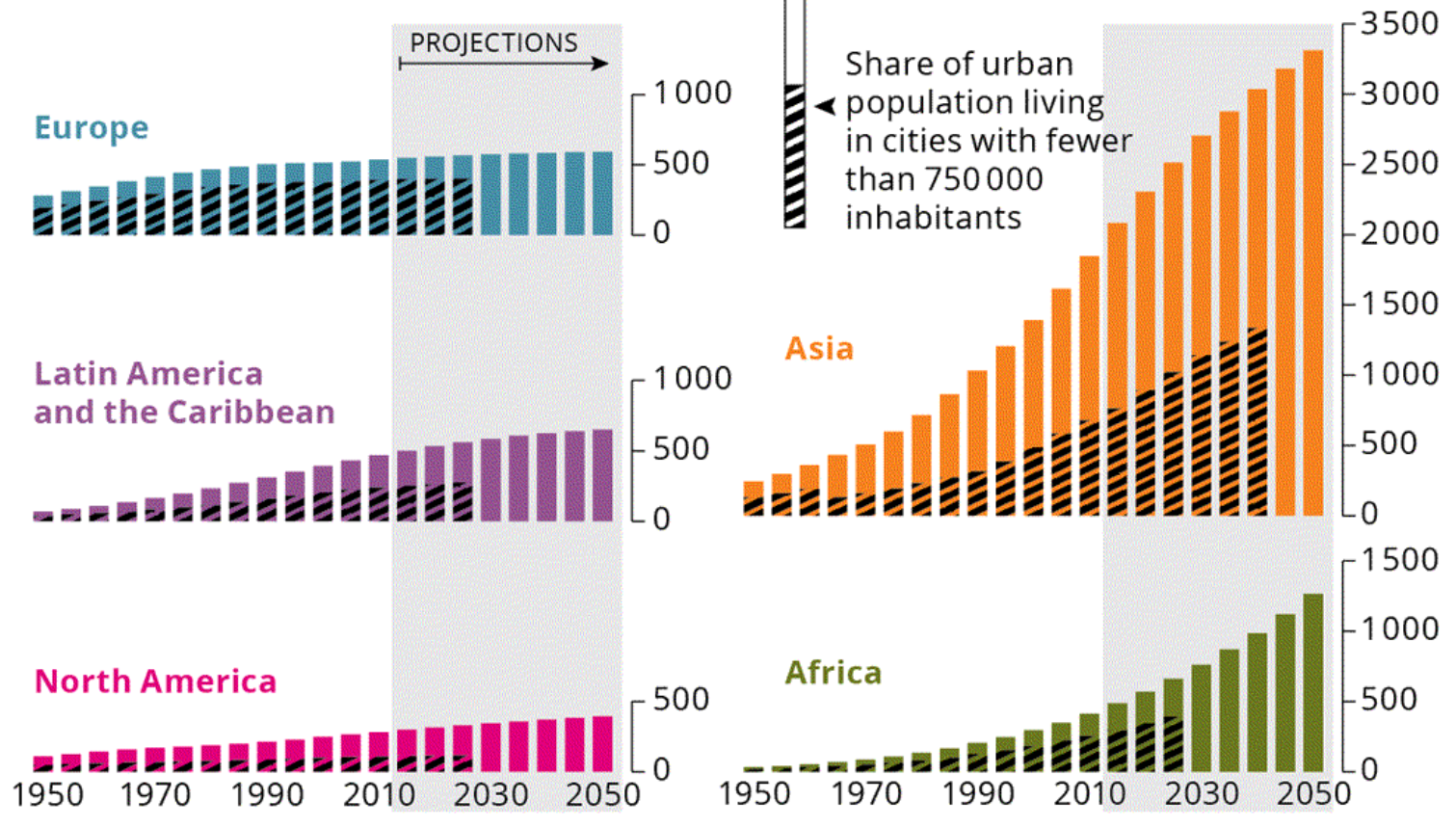

Source: EEA (2015), available at http://www.eea.europa.eu/soer-2015/global/urban-world. The figure is reproduced with the EEA's permission. We acknowledge also the UN which provided the underlying data.

As the papers in this volume demonstrate, while urbanization is happening everywhere, its outcomes are strikingly different. As Edward Glaeser and Wentao Xiong show in a review of Asian and Latin American experience, the most striking success has been China. The society managed an unprecedented pace of urbanization, while building cities that were sufficiently productive to enable an equally unprecedented increase in incomes and, subject to significant qualifications in respect of air quality, were adequately liveable, with major expansions in public services. Glaeser and Xiong's regional overview is complemented by an in-depth case study of the political economy of South Asia's principal megacity, Mumbai, by Shahana Chattaraj and Michael Walton. Mumbai has been sufficiently successful to host a transformation in productivity, but has not delivered liveability for the mass of its inhabitants.

African urbanization has been less successful: Paul Collier (2017b) reviews the experience of the region, concluding that it has not enabled a transformation in productivity, while there have been severe sacrifices in liveability. The analysis of Africa is deepened through case studies of Lagos (by Nic Cheeseman and Diane de Gramont), Luanda (by Allan Cain) and Nairobi (by Julia Bird, Piero Montebruno, and Tanner Regan). Lagos, Africa's only coastal megacity, is being restored from decades of dysfunction. The turnaround has been coincident 
with the transition to democracy, and consequent accountability of leaders to citizens. In Luanda, despite strong Chinese involvement, the Angolan government did not adopt Chinese policies. Instead, oil revenues were invested in a residential satellite town reliant upon commuting by private car, and designed for high-income occupancy. The outcome was both regressive and dysfunctional, intensifying extreme traffic congestion. In Nairobi, informal settlement in a large inner-city slum froze land-use into low productivity, while offering modest opportunities for the gradual improvement in the quality of life. These divergences in outcomes are due to underlying differences in public policies, as discussed in Somik Lall's paper.

This overview paper is in two main parts. First (in section II), we look at aspects of the urban economy and the reasons for such diverse performance. Cities offer the benefits of scale and specialization with consequent high productivity and job creation, yet many developing cities have chronic failure to create sufficient jobs for their fast-growing populations. Land is the scarce factor, but its use is often highly inefficient. Housing is necessary both for liveability and productivity, but obstacles to investment mean that in many cities the majority of the population lives in slums. In each of these areas policy plays a critical role, in setting the legal and institutional environment in which cities operate, in providing infrastructure and public goods, and in coordinating the development of a growing city. Sections III and IV of the paper look at the tasks that policy needs to perform and at the reasons why it has failed, arguing that cities are particularly 'policy intensive' and that, in many cities, policy failure is deep-rooted in inappropriate structures of policy authority.

\section{Urban economic performance}

\section{(i) Jobs and productivity}

Part of the movement to cities is barely economic: young people crave the greater social interaction, liberation from family authority, greater variety, and basis for hopeful dreams that cities offer. But it is underpinned by the fundamental drivers of jobs and productivity. Cities are better places to undertake most sorts of investment, to start new businesses, and thereby create jobs. The reasons are well documented. Investment occurs in places with access to large markets, to suppliers of intermediate inputs and utilities, and with good supply of workers of appropriate skill levels-features notably absent in villages and small towns. Cumulative causation cuts in as cities grow_enlarging the urban market and set of suppliers, and creating an environment where it pays firms and workers to specialize in narrow skills, confident there will be a market for these skills.

The research literature on developed economies has quantified these agglomeration effects in estimates of the elasticity of productivity with respect to city size (or 'access to economic 
mass' more generally). These estimates suggest an elasticity of around 0.05 , so that going from a city of half a million to one of 5 million raises productivity by around 12 per cent. The effect is much larger in sectors that are particularly prone to agglomeration, such as finance and knowledge-intensive sectors.

What do we know about the scale of these effects in developing cities? The paper by Glaeser and Xiong (2017) is one of the first to address this question, and finds larger effects in Asian countries than in the developed world. For China and India effects are around twice as large, implying that in China urban wages are 45 per cent higher than rural wages, while in India the differential rises to 122 per cent. The elasticity of productivity with respect to wages in Brazil is similar to that in the US, but large enough to support productivity in São Paulo that is 90 per cent higher than in the rest of Brazil.

At lower income levels the picture becomes more mixed. At one extreme, Bangladesh has rapid urban growth driven largely by the ready-made garment sector, an urban cluster employing more than $4 \mathrm{~m}$ people, largely in Dhaka and Chittagong. At the other, Africa (subSahara) has almost entirely failed to attract internationally tradable sectors in which scale can be achieved and agglomeration economies are to be expected, as discussed in the paper by Lall (2017). Instead, there is production for the local market and extensive informal employment (more than 80 per cent of the labour force in many African cities), as formal job creation has fallen far short of population increase.

There are multiple reasons for the lack of competitiveness of African cities. Some are features of the country as a whole. The overall business and political environment matters, and in some countries dependence on natural resource exports creates a 'Dutch disease', giving a relatively high exchange rate which undermines the competitiveness of non-resource tradable sectors (see Gollin et al., 2016). Other factors are features of the urban environment. Investment in urban infrastructure has lagged behind population growth, leaving cities without the transport systems needed for firms to access markets and suppliers, and for workers to access jobs. Inadequate power supply leaves firms dependent on their own generators. These factors, together with poor housing and public service provision, raise urban costs and deter investment. The consequence is that the only sectors that invest are those producing non-tradable goods for the local market, sectors whose protection from international competition means that they are able to pass on their high costs to local consumers (Venables, 2017). Non-tradables range from products such as beer and cement through to retail and the informal sector of services and street markets.

Together these factors create a vicious circle. Booming but dysfunctional cities are expensive, as documented by Lall (2017), who shows how fragmented urban forms tend to raise urban costs. They may appear to have high productivity, offering higher nominal wages than rural areas, but these wages are reflections of the high prices at which non-traded output can be sold and the high costs of urban living. They do not reflect high productivity in 
tradable sectors - sectors which are absent because of high urban costs and nominal wage rates.

Despite the low productivity and quality of life in African cities, they nevertheless attract migration from rural areas. The paper on Nairobi (Bird et al., 2017) demonstrates that indicators of living standards in Nairobi - even its notorious slums - exceed those in Kenya's rural areas. In much of Africa, agriculture is overwhelmingly rain-fed and vulnerable to drought, with the Sahel and Southern Africa already facing adverse consequences from global warming. The rural economy is more heavily dependent upon agriculture than are other developing regions, and offers fewer opportunities for employment in activities with potential for gains from scale than do urban areas.

\section{(ii) Land and rent}

The opportunities provided by a city create demand for its scarce factor-land. The rent on land plays two roles, as do all prices: it allocates land between competing users, and is a financial payment, transferring wealth from payer to payee. In a perfectly competitive market the first of these roles generates an efficient allocation of land. The textbook model-city has jobs concentrated in the city centre as firms gain from clustering together and from having good access to consumers and workers from across the city. The remainder of the city is principally residential, with rents highest in the centre and declining with distance as those further out face the costs of commuting to reach the centre. The rent gradient induces high building density in the centre, and lower density towards the suburbs.

The second role of rents is the financial transfer made, in a private ownership economy from occupant to land owner. This rent flow will be capitalized in land values which, in the largest cities, creates massive wealth for land owners. Importantly, land rent is rent in the economic sense, as well as the colloquial. Demand for land comes not from any action of the owner but from the fact that it is located in the city, and so benefits from the infrastructure that has been built and from the multiple externalities associated with agglomeration economies. As such, the land owner has no moral claim to the rent, making rent (or land values) an ethically attractive base for taxation. The case for taxing land is strengthened by three further arguments. Taxation of land is relatively easy to administer, precisely because it does not move and its ownership can be - although is not always - well documented. Taxation of pure land rent is non-distortionary, although in practice taxation often takes the form of joint taxation of land and the structure on it. And, under some quite special assumptions, the value of land in a city is sufficient to finance all of the efficient level of provision of infrastructure and public goods - the 'Henry George theorem'.

\footnotetext{
${ }^{1}$ See Arnott and Stiglitz (1979). The simplest form of this theorem is derived in a model in which the supply of labour to the city is perfectly elastic, so real wages are fixed. Any surplus created by the city must therefore
} 
How do land markets work in developing cities? There are enormous cross-country and cross-city differences as institutional structures have evolved from traditional systems in different ways. Inefficient allocation of land and patterns of land-use is a common problem, principally because of lack of clarity about land ownership and consequent insecurity of tenure. In many cases, customary land rights have been modified or removed, but have seldom been clarified. African urban land rights are confused and contested, with co-existing systems of private ownership (some illegal or quasi-legal), communal ownership, and government ownership. The same piece of land may have several claimants, each supported by some sort of documentation. The number of claimants increases in response to likelihood of development as ownership becomes more valuable, leading to lengthy court cases which compete with informal de facto possession. Around 80 per cent of African court cases are about contested land ownership, and legal titles, often with dubious histories, are insufficient to enable the eviction of those who occupy the land without title and so have de facto possession.

The immediate consequence of these confused land rights is to deter investment in formal structures. These are long-lived and construction costs are largely sunk. Given the risks attached, it is unsurprising that construction is informal, involving few sunk costs and capital assets (e.g. iron-sheeting) that can be recycled and re-used. Successful urbanization needs secure and marketable land rights. Without security, people will not invest in building structures. As Bird et al. (2017) show, while households in Nairobi's inner slum areas have been willing to do some upgrading on their homes, this has been confined to internal features such as flooring, rather than building extra storeys, which would provide an expansion in floor space. ${ }^{2}$

Marketability is also critical because without it the use of land ossifies. As the city grows, land on the edge of the city should switch function from agriculture to settlement; and as land near the centre becomes more valuable, the activity that is appropriate for it will change. However, in many developing cities low-value land-use and low-density buildings persist in potentially high-value areas near city centres. In many cases it is difficult to convert informal use to formal; the paper by Bird et al. (2017) discusses this issue in Nairobi. ${ }^{3}$ Business development is also impeded as it is hard to assemble the sizeable plots of land that are required. The difficulty arises as land transactions require clarity of ownership to establish that a seller has a valid status; an observable comprehensive record of ownership of each parcel, so a potential purchaser can approach the owner; and an observable record of prior transactions to facilitate valuation. Meeting these requirements makes establishing a market in land far more demanding than a market in commodities.

accrue to land, the only other claimant. It cannot be optimal to spend more on infrastructure and other public goods than the surplus it creates (equal to land value).

${ }^{2}$ That is, improvements with a short pay-off period. See Marx et al. (2013) for further study of Nairobi's slums.

${ }^{3}$ See also Henderson et al. (2016) who suggest that the cost of failure to convert is as high as $\$ 13,000$ per slum household. 
The capture of rents and land value appreciation and its use to finance infrastructure and urban development has been employed effectively in China. As Cain (2017) discusses, China combined state-ownership of land with considerable delegation of political authority to the city level. Cities gained authority over surrounding rural areas and the ability to convert land from rural to urban use, paying compensation at rural values. This is typically a fraction of the (urban) market values, and the difference enabled mayors to finance investment in infrastructure at a rate without global precedent. Other countries have state ownership of the land, but few have exploited this technique. Among reasons for this is the fact that it works conditionally_land values are high in early stages of urban development only if there are positive expectations about the future growth of the city, expectations which depend on the overall growth of the economy and the capacity of government to deliver city growth. Large projects undertaken jointly between the city government and private developers can coordinate business expectations on particular locations within the city, transforming the value of the land. While the coordination achieved by such partnerships generates economic value, whether or not this value is captured and used to finance infrastructure depends upon further policy choices. The Eko Atlantic project in Lagos, discussed by Cheeseman and de Gramont (2017), generated economic value but directly benefited high-income groups. Similarly, in Mumbai, the redevelopment of land that had been used for textile mills for new businesses generated economic value, but much of this was captured by private interests (Chattaraj and Walton, 2017).

An alternative - or addition - to capturing land value appreciation is a continuing tax on land or property. This is practised in most developed countries and many developing, although its implementation has often proved difficult and it typically raises a very small share of revenue, estimated at less than 0.5 per cent of GDP in many African countries (Fjeldstad and Heggstad, 2012), one quarter the average share in OECD countries.

Fundamentally, in most countries the ownership of urban land is politicized. Powerful people, such as politicians and senior civil servants, have used their positions to establish some claim to legal title. Corruption adds a further layer of confusion, both at the small scale-bribery for allocation of permits - and at the large. For example, the Kenyan elite has been guilty of land-grabbing, with a government inquiry alleging that the land allocation process has been subject to corrupt and fraudulent practices and 'outright plunder' (Southall, 2005). Slum areas are particularly complex, with 'planning or regulatory powers . . split between a galaxy of private sector actors, landlords, chiefs and bureaucrats, and gangs' (Marx et al. 2013, p. 198).

It is difficult to generalize about the treatment of land and rent in developing cities, but Chattaraj and Walton (2017) make the point that even chaotic systems can function. In their study of Mumbai they point to 'functional dysfunction' and argue that while 'rents are linked to inequalities, illegal transactions, and sources of distortion in economic functioning, it is important to recognize that they do work ... the city functions'. 


\section{(iii) Housing}

The dominant feature of the residential housing stock in developing cities is its low quality and, at its most extreme, the prevalence of slums. While slum populations are hard to estimate accurately (and slums hard to define precisely) it is estimated (UN-Habitat, 2016) that some $881 \mathrm{~m}$ people worldwide are slum dwellers, and in Africa 56 per cent of the urban population live in slums.

What are the causes? The confused legal rights outlined in the previous section are a major cause, and are compounded by several further factors. ${ }^{4}$

\section{Inappropriate regulation}

Building standards have a variety of functions. For example, they ensure that the foundations of a building can be ascertained by buyers, despite being unobservable. They also protect people against known psychological biases, such as discounting the future too heavily.

Regulation of building standards is necessary, but standards have to be set at an appropriate level. Many African cities have regulations that are inappropriately high (partly as a result of inheriting standards set for Britain in 1961). Thus, in Nairobi the minimum legal plot size is $250 \mathrm{~m}^{2}$, which is unaffordable for ordinary households. Not only were these inherited standards not revised downwards, they conveyed the impression to African regulatory authorities that modernization would require standards to be raised from time to time. Hence, in Dar es Salaam the minimum size of plot is $500 \mathrm{~m}^{2}$, but the authorities are discussing whether to raise it to $700 \mathrm{~m}^{2}$. Other regulation has similar effects. Restrictive floor-area ratios (FARs, or floor space index, capping floor area to plot size) raise costs and restrict building height. In Indian cities these ratios are typically low, encouraging sprawl, raising commuting costs, and harming connectivity. ${ }^{5}$

The effect of these standards has been to make legally compliant building unaffordable to middle- and low-income households. The inevitable consequence is that housing construction has bifurcated, with regulations being ignored in the informal market that caters for ordinary households. This informality brings other costs. Designs are idiosyncratic and buildings' foundations unobservable, meaning that properties are hard to value. Being hard to value impedes the resale market and the use of property as collateral.

\section{Finance and construction}

Building a city requires capital and construction, as well as land. Housing finance has generally not been well-served by the commercial banking sector. In nineteenth century Britain urbanization triggered innovation in the mortgage market through building societies

\footnotetext{
${ }^{4}$ This section draws on Collier and Venables (2015).

${ }^{5}$ See Bertaud and Brueckner (2005), and for an overview, Brueckner and Lall (2015).
} 
which were able to out-compete banks because they had lower administrative costs and lower risks and so could work on narrower spreads. The set-up costs of a loan could be spread over many years and default was limited by good collateral. Not only were spreads low, but in nineteenth century Britain inflation was very low, so that nominal interest rates could be low. Building societies were also able to build a large deposit base from ordinary savers.

Although some African cities have building societies, they cater to either high-end housing or to civil servants. Inflationary expectations mean that typical terms on African 'affordable' mortgages are an interest rate in excess of 20 per cent and a term of only 10 years. Unsurprisingly, defaults are concentrated in the first 2 years of the loan when real terms repayments are at a maximum. The upshot is that mortgages only cater to a tiny elite: around 3 per cent of households. Hence, in Africa the normal financial engine of investment in residential structures is not able to function.

A common policy response has been to place ceilings on interest rates, or to offer subsidized public mortgages. For example, the Nigerian government has provided mortgages at 6 per cent at a time when the market interest rate was 18 per cent. Evidently, this is not fiscally viable at any scale. A more viable policy might be to introduce indexation of mortgages, enabling repayments to be stretched over a much longer period. There may also be scope for building societies to mobilize untapped savings through the new techniques of e-banking, as has been pioneered in Kenya. By matching the indexation of their mortgage assets with the indexation of their deposit liabilities, building societies could have a safer business model. It is important for housing finance to attract domestic savings because, not being an export sector, it would expose foreign finance to an exchange rate risk that would require a corresponding level of interest rates.

\section{Affordability}

Low-quality housing is, in part, a natural corollary of low incomes. As we saw above, Africa is urbanizing at relatively low levels of per capita income, so providing decent housing is hard to afford. ${ }^{6}$ Yet from the experience of some cities, such as Addis Ababa's housing programme, it is possible to provide four-room apartments (including bathroom) in fivestorey blocks at a construction cost of around $\$ 10,000$, plus a further $\$ 3-4,000$ for infrastructure and administration. These are affordable with mortgage finance (at 9.5 per cent) for families with incomes as low as $\$ 2,000$ p.a. (Franklin, 2016). ${ }^{7}$ The more commonly observed residential pattern, so different from this, suggests policy failure surrounding three key issues which we consider in turn.

\footnotetext{
${ }^{6}$ There is evidence that housing investment as a share of GDP starts to rise sharply only once per capita income levels pass $\$ 3,000$.

${ }^{7}$ Land costs are estimated at up to a further $\$ 6,000$, and are heavily subsidized by government.
} 


\section{The three tasks that public policy needs to perform}

Policy is critical for successful urbanization because three activities, each of which is essential, cannot be provided by the market and so must be undertaken by public authority. These are provision of non-market infrastructure, regulation, and coordination. We consider them in turn.

\section{(i) Public goods and infrastructure}

The built city is the result of three complementary investment processes: housing done by households, commercial investment done by firms, and infrastructure done by government. The infrastructure is needed both to make the city productive and to make it liveable. Transport infrastructure is vital for connectivity, and power grids for cost-effective energy. Water and sewerage networks are vital for public health, and public buildings are needed for services such as education and health.

In the nineteenth century cities of the OECD, this public infrastructure of cities was a defining feature of development. New network transport technologies were developed, such as underground railways; gas and electricity grids radically reduced the cost of energy to firms and households; public health infrastructure reversed the sharp decline in life expectancy that initially characterized urbanization; and primary education expanded from being for a minority to being universal.

The Chinese government has achieved a similar transformation even more rapidly, but in most developing cities infrastructure and public services have not kept pace with settlement. The provision of public services, ranging from health and education through to water supply and sanitation, is generally weak, although much better in urban areas than rural. The inadequacy of power supply is widely documented. Whereas Africa had three times more generating capacity per person than South Asia in 1970, it now has just half as much: the density of paved roads in sub-Saharan Africa is less than one-quarter of that in other lowincome regions (Foster and Briceño-Garmendia, 2010). Within cities, roads are inadequate. For example, roads constitute only around 10 per cent of the land area of several large African cities, whereas in a well-connected large city the figure would be around 30 per cent. Freetown is an extreme instance: during a period of state breakdown the city's population grew to over a million as a result of violent disorder in rural areas, but it still has little more than the colonial road network designed for a town of 35,000. As a consequence, the few roads become highly congested as private users of cars ignore the negative externalities they generate. These externalities are not just on other car users, but on buses.

The financial challenge of providing urban infrastructure is enormous, and can amount to as much as 10-20 per cent of urban gross value added (GVA) over many years. Municipal budgets are generally a small fraction of these amounts, and local governments generally 
have limited taxation authority. This varies across countries with, for example, local taxes in Ghana virtually non-existent. Foster and Briceño-Garmendia (2010) estimate that most African cities are dependent on central transfers for more than 80 per cent of their operating revenues, and that local government revenues generally account for less than 1 per cent of GDP.

Lagging provision and constrained finance give rise to unstable dynamics. As infrastructure falls behind, the political imperative becomes to devote budget to retrofitting it. But retrofitting infrastructure post-settlement is both more expensive and faces far greater political obstacles than installing it on green-field sites. The high cost further diminishes the resources available for green-field sites, so that a yet higher proportion of new settlement lacks infrastructure. Cumulatively, this has led to a generalized shortage of public infrastructure. Levels of connectivity have often fallen sharply due to rising congestion, while power grids have become so inadequate that self-provision by means of diesel generators has become the norm for businesses. In many places economic infrastructure has fared even less well than social infrastructure (health and education), as shown by Bird et al. (2017) for Nairobi, possibly due to the low priority given to it by donors.

\section{(ii) Regulation}

Regulation includes rules, the process that generates them, and the organizations for enforcement. The rules that are distinctive and critical for urbanization are those concerning the occupation of land, migration, building standards, public health, and the management of congestion.

\section{Regulation of land and building}

As we saw in section II(iii), land and building requires appropriate regulation of land-use and building standards. It also needs to be underpinned by a legal and administrative capacity that is effective and honest.

All well-functioning urban land markets rely upon some form of public register of ownership, backed up legally by recourse to a reliable judicial process, and physically by a police force that is willing and able to enforce court decisions. Attempts to introduce legal title have been hampered by the absence of a transparent and participatory process of establishing a public register. This has been compounded by weaknesses in the court system. Court decisions are notoriously open to bribery: even in Ghana, widely regarded as one of the African societies with the best governance, a recent sting operation generated video-evidence of 27 judges taking bribes. This has provided opportunities for those individuals with money and political influence to mount claims to title through the courts: for example, the legal title to much of the land in the Nairobi slum of Kibera is held by politicians, army officers, and senior civil servants, while those who actually live in it are long-term squatters. 
A further consequence of a weak legal system is that property does not function as collateral. Even if there is a reasonable degree of clarity, for property to function as collateral requires that a creditor can foreclose on the property in defined circumstances of arrears. This in turn depends upon the law, and the reliability and speed with which courts implement it. The common experience has been for delays in court proceedings and judicial corruption to make foreclosure unreliable.

As to an observable and comprehensive record of ownership, this demands a public bureaucracy with competence and integrity. China was able to establish such a record, aided by the fact that all land ownership was initially vested in the city authority. In Africa only Rwanda and Ethiopia have been able to establish them, the administrative cost being $\$ 6$ per parcel in the former and around $\$ 1$ in Ethiopia. In both cases, registration was accomplished quite swiftly through national programmes.

As to the ease of valuation, many transactions are currently the outcome of unmediated negotiations between buyer and seller and so there is neither an incentive to reveal price information, nor a means of recording it.

The evident weaknesses in the security and marketability of urban land ownership in most poor societies may help to account for the stark contrast with urbanization in China. As both Glaeser and Xiong (2017) and Cain (2017) show, Chinese policies have been remarkably successful in creating cities that are reasonably productive and liveable despite extraordinary rates of urban growth. In part, this was because in China mayors controlled land rights.

\section{The regulation of public health}

The need for regulation for public health arises from the evident scope for disease externalities of private decisions, especially severe in contexts where habits formed in lowdensity rural areas where they are safe, are brought to high-density urban settings where they are dangerous, as a result of rural-urban migration. Regulations are needed to limit overcrowding, and to overcome the 'last mile' problem in the connection to networks of piped water and sewerage.

In China the city authorities managed to keep ahead of settlement, so that the essential infrastructure for water-related public health became near-universal, although air pollution was left uncontrolled, resulting in massive damage. ${ }^{8}$ In Africa, key metrics of water-related public health, such as the proportion of urban households with access to piped water, have deteriorated substantially as settlement has outpaced new infrastructure and as regulations have been evaded.

\footnotetext{
${ }^{8}$ See for example Chen et al. (2013) for a study suggesting that unregulated coal burning in the north of China reduces life expectancy by 5 years.
} 


\section{The regulation of congestion}

Traffic congestion arises from the tension between the individual and the public interest in the use of private cars. In the cities of the OECD, the usual solution has been to regulate the access of cars by means of bus lanes. In the cities of poor countries, with virtually no investment in non-road public transport systems and much smaller road networks, the dangers of congestion are more acute. Yet bus lanes are very rare. Indeed, a more common form of regulation has been to curtail private minibuses, which are probably the most costeffective and affordable means of urban transport.

\section{The regulation of migration and fertility}

The individual decision to migrate to a city can have externalities for others. Indeed, one of the earliest models in development economics, that of Harris and Todaro (1970), showed that rural-to-urban migration would be socially excessive because new arrivals would reduce the chances of employment for the existing pool of job-seekers. Updating the idea to the twentyfirst century, such negative externalities may be more powerful in respect of land and public services than employment. Where informal occupancy confers de facto possession, migration is not merely a relocation of a worker but a 'land grab' in miniature. Cumulatively, in most low-income cities, huge tracts of land have been informally privatized in this way. Similarly, even informal urban residence may radically improve access to public services such as education and health, as shown by Bird et al. (2017) in respect of Nairobi slum dwellers. In contrast, China has successfully curtailed informal settlement, partly by policing land occupancy, but primarily through the hukou system that has restricted the right of rural dwellers who migrate to cities to access public services and employment.

The regulation of fertility is a related, and dramatic difference between China and other developing regions. The one-child policy contrasted with the unprecedented pace of population growth in the other regions and had evident corollaries in divergent speeds of urban growth.

\section{(iii) Coordination}

The formation of a city is a coordination process that cannot fully be resolved by the market. While there are huge gains from clustering, ex ante these gains could usually accrue at many different locations. The future value of land thus depends upon future decisions that are interdependent and so unknowable. Public policy can thus play a valuable role through coordinating these expectations, thereby reducing the uncertainties of the investment process. In turn, this reduces investment mistakes and accelerates the development of the city.

It is well understood that the solution to the dilemma of coordination is to generate common knowledge. In the OECD, city authorities usually do this by means of published plans that forecast the provision of transport infrastructure, and zone the city according to differentiated 
uses. Areas designated as residential will have regulations limiting the nature of commercial activities; 'golden triangles' with some privileges will be used to regenerate commerce in areas that have become rundown; and industrial zones will be designated on the periphery.

In poor countries, many cities lack such plans. For example, for many years Dar es Salaam had no plan (Collier and Jones, 2017). But even when plans are made, they may have limited credibility because of a weak record of implementation. For example, the Kampala ring-road, opened in 2011, was first announced as a plan in 1973.

\section{Why policy goes wrong}

The contrast between the relatively successful public policies of mid-nineteenth-century Europe and America and late-twentieth-century China, on the one hand, and the failures of policies to achieve either productivity or liveability in many other places, demands explanation. The proximate mechanisms that shape public policy are the rules that are set through legal and administrative processes; the efficacy of the public organizations that are legally mandated to design and implement particular policies; the opinions held by those citizens who constitute a critical mass that cannot readily be ignored; and the authorizing environment that is responsible for the rules and organizations, and which can readily communicate with citizens. We first discuss these mechanisms and finally turn to the underlying forces that determine them, namely the interests and ideas that are often distinctive to each society.

\section{Authorizing environments}

The primary explanation for the large differences in policies between cities such as Mumbai, Luanda, Lagos, Shanghai, and Nairobi is the differences in their authorizing environments. Urbanization needs a spatial span of control large enough to encompass the future economic domain of the city, a temporal span of control able to manage long-term planning of infrastructure, and a functional span of control able to coordinate many different types of activity. Since such an authority would have massively concentrated power, it would need a correspondingly powerful system of checks and balances to prevent abuse. Only Chinese cities have had authorizing environments with a sufficient span of control, but the checks and balances to which they have been subject, namely national political authority, have been insufficient to prevent errors such as air pollution, and abuses such as corruption. Urban authorities in other regions struggle with each form of fragmentation.

Nairobi does not even have a spatially unified urban authority: the city has expanded far beyond its original boundaries and the geography of authority has not kept abreast of the geography of settlement. Lagos is unusual for Africa in being a primate city with a unified authority. This is not by design, but the fortuitous consequence of the federal structure of 
authority in Nigeria. Lagos State has the same authority as the other 35 states of Nigeria, and encompasses the entire urban area and its foreseeable expansion. Nevertheless, the policies needed for Lagos to be successful have faced an acute problem of divided authority. As in most African societies, the primate city has usually voted for the opposition party, and so national policies have not been well coordinated with city-level policies. Indeed, national governments have at times seen the interests of their primate city as being subordinate to those of rural areas. In contrast, Shanghai and the other major Chinese cities have a central entity to which much authority has been decentralized by national government, combined with a relationship to the national level that is aligned and reasonably clear. As Cain (2017) emphasizes in his study of Luanda, the former socialist societies have a major advantage in urbanization in that the state is legally and culturally empowered to allocate land, and this enables the urban infrastructure to be financed from land sales. The African equivalent to China in this respect is Ethiopia. Paradoxically, despite its political legacy, the government of Angola has not availed itself of this opportunity.

Analogous to an appropriate spatial reach, an authorizing environment needs an appropriate temporal reach. Planning for urban growth requires a horizon of at least a decade: future settlement needs to be anticipated, and the necessary infrastructure will take several years to build and longer to pay off. Since democratization around 1990, the horizon for most African authorizing environments has shortened owing to 4-year electoral cycles. Here the contrast with China is stark: public organizations are accustomed and expected to plan decade-bydecade, not year-by-year.

This fragmentation of authority is also functional. The issues to be addressed in a city span the range from practical engineering, through health and education, to financial and legal, i.e. covering the domains of many government ministries. The resulting coordination problem is compounded because the delineation of authority is unclear both between local and national government, and between numerous ministries within national government. Practical authority is often highly concentrated in Presidencies and Ministries of Finance, but this creates a logjam of policy disputes awaiting resolution among low-ranking and disputed issues such as urbanization.

Authorizing environments need checks and balances. If the checks and balances are too weak, mistakes are not caught in time; if they are too strong, change is too easily blocked. Urban China and urban India are at opposing ends of this spectrum. The highly concentrated nature of authority in China has enabled remarkably rapid implementation of urban plans, but this has come at the expense of severe mistakes, most notably environmental pollution. India has among the strongest systems of checks and balances in the world, an objective measure being the count of veto points (Beck et al., 2001). But the price of these restraints has been the blocking of useful change, an example being the inability of Tata to develop a car assembly plant at Nana Singur because of the veto power of local farmers. 
The weaknesses of authorizing environments in urban Africa has sometimes been recognized and addressed. In 2011 Ugandan President Museveni reorganized Kampala, turning its management into the status of a ministry, and appointing a technocrat as its chief executive. Her first actions were to dismiss all the senior staff of the city authority, rehiring only selectively, and changing all job designations. As a motivated team was built around a repeated narrative of building the future city, there was a substantial improvement in planning and implementation.

\section{Public organizations}

The effectiveness of public organizations depends partly upon the individual skills of its staff, but primarily on whether people are able to work together as a motivated team, aligned to the public interest. Again, China is at a considerable advantage: its strong national identity and continuity in government has made it easy to align staff with their role in building the nation. In Africa, the combination of weak national identity and short horizons has made it difficult to build motivated public-sector teams. As noted above, for many years the urban authorities of Dar es Salaam had not even got a plan, while in Kampala the plan for the bypass road was left unimplemented for over 30 years.

Given the enormous economic rents generated by urbanization, and the weakness of Chinese checks and balances, it is unsurprising that this motivation has been heavily contaminated by corruption. But in contrast to much of Africa, the corruption has usually been bounded by core public interests. Thus, many of the deals that sold public land to developers may have enriched officials, but the take was a margin on a transaction whose core function was to generate revenues for the city, whereas African urban land deals have essentially bypassed the state, exclusively enriching powerful individuals.

\section{Rules}

As discussed above, good regulations are critical. Many of the vital rules are national laws and so depend upon parliaments and judges. Typically, neither group understands the economic significance of the rules that it sets. This is especially the case for land ownership: the judicial process is geared to establishing case-by-case rights in disputes, and is disconnected from the implications for economic policy, whereas parliaments are often dominated by rural interests and opportunists. The key national agency that should be guiding the rule-setting process is a ministry of finance and planning. Only such a ministry has the required combination of technical skill, political heft, and time horizon. But usually ministries of finance are distinct from planning: focusing on the short term, they have ignored urbanization.

\section{Citizen opinion}

Citizen opinion matters in two distinct respects. Depending upon the level of trust in government, it can make compliance with public policy more or less difficult; and whether 
citizens understand the difference between smart and mistaken policy can influence its content.

The opinions of ordinary citizens directly determine the severity of the compliance problem that faces all governments. In respect of taxation and regulations, government tries to get citizens to behave in ways that are not in their individual short-term interest. An efficient process of urbanization is heavily dependent upon easy compliance, from whether cars violate bus lanes, to whether settlement can be controlled. The ease of compliance depends upon trust in government. The Chinese authorities, with a long tradition of state power, have inherited far easier compliance than those in Africa. The former have not only been able to regulate where people settle but, almost uniquely, to control rural-to-urban migration through the hukou system that limits access to entitlements.

Some citizens - the 'critical mass'-are collectively influential in public policy. Good policies on urbanization thus depend on whether this group is well informed. Both the size of the group, and the extent to which it is informed, differ considerably between societies. Again, China is at an advantage: the concentration of power in the executive and the higher reaches of the Communist Party, combined with the prestige of technocratic education, have built a critical mass that understands many of the complexities of urbanization. Again, Africa, with its democratic institutions and a poorly educated and predominantly rural electorate, is at the other end of the spectrum.

\section{Interests and ideas}

Finally, we turn to the forces that are likely to account for the above differences in mechanisms: underlying differences between societies in interests and ideas.

The predominant explanation for policy choices offered by political science is the interests of those who have acquired power. A key distinction is between 'common interest' states, in which power is exercised in the perceived interests of citizens, and 'repressive' states in which it is exercised in the interest of elites. ${ }^{9}$ This distinction does not necessarily match with that between autocracy and democracy: in autocratic states, such as China and Ethiopia, those in power may nevertheless be motivated to pursue the national interest, while in democratic states, such as Nigeria, politicians may abuse their power for individual enrichment or ethnic favouritism. The pattern of land ownership in Kibera, the central slum district of Nairobi, where legal title is concentrated in the hands of non-resident politicians, army officers, and senior civil servants, points to such abuse. The otherwise puzzling case of Chinese activity in Luanda is a yet more dramatic example of elite interest in a democracy. Despite relying heavily upon the Chinese to manage urbanization, the Angolan authorities have not adopted Chinese urbanization policy. On the contrary, it has merely used Chinese construction companies and finance to build ill-planned high-income housing at enormous cost to the national budget.

\footnotetext{
${ }^{9}$ Besley and Persson (2011).
} 
Ideas as well as interests matter (Mukand and Rodrik, 2017). Whatever interest those in power pursue, their policy choices depend upon their understanding of causal relationships. For most people, an important source of understanding is the narratives that circulate within their social networks (Collier, 2016). This opens the scope for misunderstanding. Similarly, the norms enforced by social pressure differ between societies, without any force equivalent to the invisible hand to guide them to those that are currently functional. ${ }^{10}$

In China, narratives of the restoration of international respect may underpin the willingness to sacrifice individual rights that might impede urban development. In contrast, in India the emblematic role of the peasant farmer may have constrained policy. African governments tend to fear the growth of cities: with weak security forces and an acute shortage of formalsector jobs, they are wary of urban protest. Often a policy goal is to slow, or even reverse, rural-to-urban migration. One of the key ways in which transformative national leaders, such as Lee Kwan Yew of Singapore, have achieved decisive change has been to reset the national narrative. Leaders need to understand urbanization and explain it to their citizens.

\section{Conclusion}

The study of economic development, which began in the 1950s, has treated urbanization as a relatively minor specialist topic. This judgement has seriously understated its importance: the spatial management of economic development is critical to the path from poverty to prosperity. This is because scale and specialization, the foundations of the transformation of productivity, depend upon a dramatic physical relocation of the workforce from the dispersed pattern appropriate for smallholder agriculture, to agglomerations. But the rational spatial decisions of maximizing individuals do not aggregate into productive and liveable agglomerations. Urbanization is replete with coordination problems that cannot be resolved solely by the market; the need for new rights and restraints that cannot be generated solely by the market; the need for investments that cannot be provided solely by the market. Only smart and well-motivated public policy can accomplish this relocation, by harnessing market processes for social benefit. Hence, policies matter far more for urbanization than for most other aspects of development.

The review presented in this paper is based on recent experience, and the future will increase the role of cities in economic development. In Africa, the sheer scale of predicted urbanization is startling, with the urban population trebling in little more than 30 years; this increase is approximately equal to the current urban population of Europe and the US combined. The effect of climate change on agriculture will add to migration pressure and reinforce the necessity of urban-based development. At the same time the ability of citiesparticularly coastal ones - to adapt to climate change will be tested. Technological change

\footnotetext{
${ }^{10}$ For a survey of the recent literature on the evolution of norms see Collier $(2017 a)$.
} 
will also shape urban development. Cities, especially in Asia, have been centres of job creation as labour-intensive manufacturing migrates to low-wage economies, and this model of economic development may be undermined by automation and robotics. On the upside, the emerging technologies of 'smart cities' offer more effective ways of city management.

The academic marginalization of urbanization has been mirrored in the attention that has been afforded it in public policy. As discussed above, even the structures of policy authority have not been redesigned so as to be capable of getting urbanization right. Yet in many poor societies, public policies over the next two decades will determine whether urbanization creates mass opportunities for productive and liveable lives, or leads to mega-slums that are prohibitively costly to rebuild. 


\section{References}

Arnott, R. J., and Stiglitz, J. E. (1979), ‘Aggregate Land Rents, Expenditure on Public Goods, and Optimal City Size,' Quarterly Journal of Economics, 93(4), 471-500.

Beck, T., Clarke, G., Groff, A., Keefer, P., and Walsh, P. (2001), 'New Tools in Comparative Political Economy: The Database of Political Institutions', World Bank Economic Review, 15(1), 165-76.

Bertaud, A., and Brueckner, J. K. (2005), 'Analyzing Building-height Restrictions: Predicted Impacts and Welfare Costs', Regional Science and Urban Economics, 35, 109-25.

Besley, T., and Persson, T. (2011), Pillars of Prosperity, Princeton, NJ, Princeton University Press.

Bird, J., Montebruno, P., and Regan, T. (2017), 'Urban Stepping Stones: The Role of Slums in Urban Development, With Evidence from Nairobi', Oxford Review of Economic Policy, 33(3),

Brueckner, J. K., and Lall, S. V. (2015), 'Cities in Developing Countries: Fuelled by RuralUrban Migration, Lacking in Tenure Security, and Short of Affordable Housing', in G. Duranton, J. V. Henderson, and W. Strange (eds), Handbook of Regional and Urban Economics, Vol. 5, Amsterdam, North-Holland.

Cain, A. (2017), 'Alternatives to African Commodity-backed Urbanization: The Case of China in Angola', Oxford Review of Economic Policy, 33(3).

Chattaraj, S., and Walton, M. (2017), 'Functional Dysfunction: Mumbai's Political Economy of Rent Sharing', Oxford Review of Economic Policy, 33(3).

Cheeseman, N., and de Gramont, D. (2017), 'Managing a Mega-city: Learning the Lessons from Lagos', Oxford Review of Economic Policy, 33(3).

Chen Y, Ebenstein A, Greenstone M., and Li, H. (2013), 'Evidence on the Impact of Sustained Exposure to Air Pollution on Life Expectancy from China's Huai River Policy', Proceedings of the National Academy of Sciences, 110(6), 12936-41.

Collier, P. (2016), 'The Cultural Foundations of Economic Failure: A Conceptual Toolkit', Journal of Economic Behavior and Organization, 126, Part B, 5-24.

Collier, P. (2017a), 'Culture, Politics and Economic Development', Annual Review of Political Science, 20, 111-25.

Collier, P. (2017b), 'African Urbanization: An Analytic Policy Guide', Oxford Review of Economic Policy, 33(3). 
Collier, P., and Jones, P. (2017), 'Transforming Dar es Salaam into a City that Works', in C. Adam, B. Ndulu, and P. Collier (eds), Tanzania: Policies for Prosperity, Oxford, Oxford University Press.

Collier, P., and Venables, A. J. (2015), 'Housing and Urbanization in Africa: Unleashing a Formal Market Process', in E. Glaeser and A. Joshi-Ghani (eds), The Urban Imperative; Towards Competitive Cities, Oxford, Oxford University Press.

EEA (2015), 'Towards a More Urban World (GMT2)', Briefing, European Environment Agency, 18 February.

Fjeldstad, O. H., and Heggstad, K. (2012), 'Local Government Revenue Mobilisation in Anglophone Africa', Working Paper 7, International Centre for Tax and Development.

Foster, V., and Briceño-Garmendia, C. (2010), Africa's Infrastructure; A Time for Transformation, Washington, DC, World Bank.

Franklin, S. (2016), 'Urban Planning, Housing Investments and Access to Credit: A Housing Lottery in Addis Ababa', unpublished, Oxford.

Glaeser, E. L., and Xiong, W. (2017), 'Urban Productivity in the Developing World', Oxford Review of Economic Policy, 33(3).

Gollin, D., Jedwab, R., and Vollrath, D. (2016), 'Urbanisation with and without Industrialisation', Journal of Economic Growth, 21(1), 35-70.

Harris, J., and Todaro, M. (1970), 'Migration, Unemployment and Development: A Twosector Analysis', American Economic Review, 60(1), 126-42.

Henderson, J. V., Regan, T., and Venables, A. J. (2016), 'Building the City: Urban Transition and Institutional Frictions', DP 11211, Centre for Economic Policy Research.

Lall, S. V. (2017), 'Renewing Expectations about Africa's Cities', Oxford Review of Economic Policy, 33(3).

Marx, B., Stoker, T., and Suri, T. (2013), 'The Economics of Slums in the Developing World', Journal of Economic Perspectives, 27(4), 187-210.

Mukand, S., and Rodrik, D. (2017), 'The Political Economy of Ideas', available at https://drodrik.scholar.harvard.edu/files/dani-rodrik/files/ideasinterestsapr10sm_dr.pdf.

Southall, R. (2005), 'The Ndungu Report: Land and Graft in Kenya', Review of African Political Economy, 32(103), 142-51.

UN (2014) 'World Urbanization Prospects', United Nations, Department of Economic and Social Affairs, New York, available at https://esa.un.org/unpd/wup/publications/files/wup2014-highlights.Pdf 
UN-Habitat (2016), Slum Almanac 2015-2016, UN-Habitat, Nairobi. https://unhabitat.org/slum-almanac-2015-2016/

Venables, A. J. (2017) 'Breaking into Tradables: Urban Form and Urban Function in a Developing City', Journal of Urban Economics, 98, 88-97. 